\title{
DEBT/ASSET RATIO AS EVIDENCE OF PROFIT-SHIFTING BEHAVIOUR IN THE SLOVAK REPUBLIC
}

\author{
Michal IŠTOK ${ }^{1}$, Mária KANDEROVÁ ${ }^{*}$ \\ ${ }^{1}$ Department of Finance and Accounting, Faculty of Economics, \\ Matej Bel University in Banská Bystrica, Banská Bystrica, Slovakia \\ ${ }^{2}$ Department of Quantitative Methods and Information Systems, Faculty of Economics, \\ Matej Bel University in Banská Bystrica, Banská Bystrica, Slovakia
}

Received 2 August 2019; accepted 15 September 2019

\begin{abstract}
Companies use different methods and techniques to transfer taxable profits to tax havens. The paper aims at analysing the influence of the relocation of the registered office of Slovak companies in tax havens in relation to the leverage ratio and the ratio of debt per sales and to verify the use of debt by Slovak firms in the transfer of profits. In evaluating these indicators, we chose two approaches. We first analysed the change of indicators only for those firms that transferred their seat to lower tax jurisdiction. The analysis is complemented by a different view, when the selected indicators are compared to a group of businesses with a link to tax havens and with no link to tax havens. Our empirical results clearly indicate the tendency that firms in Slovakia benefit from the possibility of transferring profits to lower tax jurisdictions via debt channels. The median values of debt ratio after the transfer of the registered office to tax havens increased by $7.8 \%$. The median value of the tracking indicator is 1.2 times higher for firms with tax haven links than for companies without links to tax havens.
\end{abstract}

Keywords: debt ratio, ownership link with tax havens, profit-shifting, tax optimization, Slovak companies, Wilcoxon signed rank test, Mann-Whitney test.

JEL Classification: F23, H25, H26.

\section{Introduction}

According to Bisnode (2018), at the end of the year 2017, 4,796 Slovak companies had ownership connections with tax havens (the annual increase recorded since 2005). There are several reasons for relocating headquarters to tax havens.

According to Krejčí (2016), Slovak and Czech companies are moving their headquarters to tax havens mainly for tax reasons (44\%) and for achieving anonymity for the real owner (44\%). Rohan and Moravec (2017) verified the Czech companies owner's reaction to the

\footnotetext{
*Corresponding author. E-mail: maria.kanderova@umb.sk
} 
newly concluded agreements concerning the tax information exchange. Their study confirms that the significant number of Czech companies' owners relocates into the jurisdictions that were not covered by the agreement on tax information exchange, using the difference in differences statistical technique. Moravec, Rohan, and Hinke (2019) identified the significant effect of profit transferring in the Czech Republic in 2013-2015. The lost in the Czech Republic was CZK 9,404 mil. in 2013 while this number even increased in following years (CZK 13,081 mil. in 2014 and CZK 10,377 mil. in 2015). Moreover, Moravec and Kukalová (2014) demonstrated that the geographical allocation among the OECD states of the inward foreigner direct investments stock is highly influenced by the social contribution burden, direct taxes burden and particularly the number of double tax treaties concluded. There are four main areas of literature regarding tax research: (a) corporate tax avoidance, (b) the information about tax expense accounted for the financial statements, (c) decision-making process in corporate government including capital budgeting, capital structure as well as organizational structure and (d) asset pricing and taxes (Hanlon \& Heitzman, 2010).

The basic channels for the shift of taxable profits to tax havens include debt utilization. Current research in the world (e.g. in the USA, Canada, Germany, Sweden or Czech Republic) has in the past mostly focused on providing empirical evidence that multinational firms having affiliates in selected jurisdictions pay lower taxes than their counterparts. Recently, in the academic sphere, attention is paid not only to proving the transfer of taxable profits, but also to the methods and techniques used for this transfer, and the effort to interpret the results achieved in relation to the set-up of specific tax systems, in the context of different unilateral tax provisions and in the environment of current trends in tax and bank information exchange agreements. Multinational firms use different tax strategies and different levels of tax aggressiveness depending on many conditions (except the above mentioned e.g. interest rates, the level of capital market development, the business sector, family ownership). In the academic sphere there are the channels of mitigating tax burden divided into two major categories - techniques and methods which use debt and those which do not.

The use of debt channels as a profit shifting method is very closely associated with thincapitalization rules, in respect of the deductibility of interest expenses as one of the most controversial issues in taxation law. According to Income Tax Act from 2015 ( $\$ 21 \mathrm{a}$ on Income Tax Act) there is a possibility to incorporate costs associated with debt such as interest up to $25 \%$ of EBITDA into tax expenditures.

Quite large body of theoretical literature claims that more internal debt is being used by a foreign subsidiary if the multinational holds another subsidiary in tax havens, mainly if the spread between tax rates in the given jurisdictions is large. As during the significant research period there were no thin-capitalization rules in force, it could be realistically assumed that debt channels perform a significant role in profit transfering behaviour in the case of Slovak companies.

Acquisition of the contribution consists in analysing the use of debt instruments as a method of profit transfering from Slovakia into selected jurisdictions and proposal of research methodology in this field that is also applicable in the field of research in other countries. 


\section{Literature review}

The academics in general coincide that affiliates resided in higher-tax jurisdictions experience strong motivation to use debt financial instruments for their projects and acquisitions, and that aggession in exploiting debt and tax complemets each other (e.g. Desai, Foley, \& Hines 2004; Lin, Tong, \& Tucker 2014; Kubick \& Lockhart, 2017). Desai et al. (2004) analysed the behaviour of multinational firms and found out the strong proof about adjusting the subsidiary's leverage ratio as well as maturity of debt as a reaction to tax incentives. According to their results, there exists a direct correlation between local tax rate and leverage ratio. Specifically, a $10 \%$ increase in tax cause $2.8 \%$ increase in leverage ratio (the most sensitive are internal debts and loans). They further state that situation on capital market caused that $75 \%$ of external financing is being substitute by loans from parent companies.

Scholes, Wolfson, Erickson, Maydew, and Shevlin (2009) documented the strong association between firms marginal tax rate and the tax benefits from additional interest deduction. The firms marginal tax rate is defined as the tax rate incurred on each additional dollar of inocome.

Isin (2018) showed a positive correlation between tax avoidance and loan spreads when examining the syndicate loans market for publicly traded companies in the USA. The results of his research identify the means through which companies are able to reduce non-tax cocts associated with tax avoidance and consequently implement strategies which constatnly reduce the corporate tax liabilities without incrementing material agency costs. Graham (1996) also prooved the tendency of having higher leverage ratio by companies in higher-tax jurisdictions than companies in tax havens.

Graham and Tucker (2006) later investigated quite large (9\% in average) annual deduction of total asset value by the use of 44 tax shelters. The observed ratio is considerably greater than interest tax deductions for counterparts. A trade-off model of capital structure that enables debt to total asset ratio to be a function of firms choice of tax avoidance was introduced by Lin et al. (2014).

They state that debt correlates inversely to corporate tax avoidance for most companies, while this relation is economically relevant. Tax aggressiveness is defined by S. Chen, X. Chen, Q. Chen, and Shevlin (2007) as management to reduce taxable income through tax planning activities.

Kubick and Lockhart (2017) carried out a research on the association between tax avoidance and firms' long term debt to total debt ratio and found strong evidence that tax aggressive companies predominantly use shorter debt maturity. According to Clemente-Almendros and Sogorb-Mira (2018) the Spanish listed firms may not use tax avoidance optimally, since reduction of tax costs could be mitigated by costs of debt. This result is consistent with Graham and Tucker (2006) who claims that debt and non-debt tax burden could substitute each other. The research of Lee, Deng, Lin, and Yang (2010) identified the optimal tax strategy for investors using mathematical analysis and modelling and showed that (for certain income structures) the tax savings by deducting one-dollar investment interest expense (subset of a debt) may be more than the tax rate on the dollar of investment income that is offset. 
Martinez and Ramalho (2014) pointed out the indicator of debt per assets as one of the key indicators to measure the tax aggressiveness of Brazilian firms. They further prooved that Brazilian family offices are more tax aggressive than the non-family ones. Blouin, Core, and Guay (2010) pointed out that some prior analysis overestimated the significance of underused tax benefits of debt financial instruments. They further claim that a lot of companies fail to benefit from additional tax shield savings and thus appeared to be underleveraged. Contrary to Blouin et al. (2010), Overesch and Wamser (2014) state that the estimated taxelasticity of internal debt exceeds the earlier findings by far, most probably due to the bilateral specification of tax incentives. Bilateral loans are crucially determined by bilateral tax-rate differentials between borrowing and lending subsidiaries. They further agree with the additional investigations that thin-capitalization rules in host jurisdictions are quite effective as an anti-avoidance measure. As tax planners often increase their leverage ratio, Maßbaum and Sureth-Sloane (2009) find that the so-called Miller equilibrium as well as decisions about firms capital structure depend significantly on tax system settings and its parameters.

Chen, Huang, Li, and Shevlin (2019) state that quasi-indexer ownership leads to greater tax savings and they further find the improvement of overall company performance leads to greater tax saving than specific focus on tax planning. Debt shifting through the use of related party finance belongs to one of the three most significant profit shifting channels under existing tax system. Among the remaining two profit transferring means include transfer pricing and the location of intangible assets (Auerbach, Devereux, Keen, and Vella 2017). Profit shifting using debt as a planning technique relies on the deductibility of interest payments under most existing corporate tax systems (an existence of hybrid instruments treated as debt in host country and equity in home country) (Johannesen, 2014; Riedel, 2018). Miniaci, Parisi, and Panteghini (2014) the great impact on debt to total assets ratio of profit making subsidiary has the multinational firm's tax rate. Firstly, the benefits from transferring debt from the parent to its subsidiary are being mitigated by increase in the parent company's tax rate. Secondly, as a result, the overall tax rate of the given multinational company risen what increases the tax benefit of interest deductibility.

\section{Methodology and data}

This article aims at assessing the use of debt by Slovak companies as a channel for profit shifting to low or zero-tax jurisdictions. The indicators are analysed, such as debt per assets and debt per sales. The examined indicator debt per assets was selected, respectively derived based on Reuter (2012), Janský and Kokeš (2015) and Desai et al. (2004), who appoints the using of debt among several other variables that capture profit shifting behaviour. We have also decided to assess changes of the indicator of debt per sales. When calculating both the selected indicators, total debt was used (total liabilities minus total current liabilities).

Firstly, we analysed the change of indicator only for those companies that have moved their registered office to a tax haven. Selected indicators are evaluated based on the comparison of median values before and after relocation, by testing a statistically significant difference in the value of a given indicator and after the transfer of the registered office, as well as by quantifying the share of enterprises in which the indicator has risen. Our analysis 
has been broadened with a different view of when we compared the selected indicators to a group of businesses with links and without links to lower tax jurisdictions. To test statistically the significant difference between selected indicators, the nonparametric Wilcoxon signed ranks test and Mann Whitney test were used because the data did not meet the assumptions of parametric t-tests. Due to the nature of the data and the high variability of the data in the evaluation, the main focus is on the median values of the ratios.

The list of Slovak firms that have moved to tax havens (2005-2015) was obtained from the Bisnode database. The financial balance sheets of all Slovak firms were used from the financial statement's dataset provided by Finstat.

Jurisdictions marked by Bisnode as lower tax ones have been divided into three categories: offshore, onshore and midshore one. The jurisdictions such as Belize, Bahamas, Bermuda, British Virgin Islands, Guernsey, Gibraltar, Cayman Islands, Jersey, Marshall Islands, the Netherlands Antilles, Man Island, Panama and Seychelles are included in the offshore category. Latvia, Liechtenstein, Luxembourg Monaco and the Netherlands fall to the onshore category while Hong Kong, Malta, Cyprus, United States of America and United Arab Emirates belong to the midshore one.

The aim of this contribution is to analyse the trends in profit-transfering behaviour, that's why we have decided to categorise the jurisdictions marked by Bisnode as lower tax jurisdictions. Some authors analyze profit transferring by testing multinational companies' ownership links to lower tax jurisdictions rather than to groups of them (e.g. Janský \& Kokeš, 2016). Classification of jurisdictions, respectively tax havens, is the most common in both academic and professional literature on onshore and offshore jurisdictions. While the inclusion of jurisdiction in the offshore category is almost automatic (so-called pure tax havens), other jurisdictions are sometimes further divided between onshore and mid-shore. A separate midshore category lists e.g. Valencia (2013), which includes jurisdictions such as Cyprus, Malta or Hong Kong. Categorization between onshore and offshore jurisdictions has attempted to adapt to Slovak conditions and trends in the use of individual foreign companies. The main difference between onshore and mid-shore jurisdictions is mainly the cost of establishing and managing a foreign company (respectively corporate structure settings) and their usability (flexibility) for different levels of tax aggression.

Offshore companies (jurisdictions) are primarily used to achieve anonymity of the ultimate beneficial owner (UBO), mid-shore companies mostly for tax optimization and tax planning and onshore companies for the purpose of asset protection, asset management and flexible arrangement of ownership relations. We have examined the Slovak companies whose owners reside in selected jurisdictions marked as tax havens (equity links - formation of international holdings).

\section{Results and discussion}

In the following part of the contribution, the focus is on analysis of achieved results of the monitored indicators before and after the relocation of the seat of the Slovak firms to the tax havens and to compare the reported indicators among the Slovak firms with ownership links to lower tax jurisdictions and their counterparts. 


\subsection{Debt ratio analysis (debt per assets)}

Based on the assumption that companies use the leverage ratio for the transfer of taxable profits to tax havens, the debt ratio will be higher after the transfer of the registered office. There is data available for 1,065 Slovak companies before and after the transfer to the tax haven. The file excluded companies that reported incorrect data (zero or negative total assets). In addition, excluded companies are also the ones where the indicator was showing outlier (2.44\% observations), which could distort the results of statistical tests. We have statistically tested and compared the selected indicator one year before and one year after the official seat transfer to tax havens (also used in case of debt per sales indicator). The resulting file comprised of 989 enterprises. In Table 1, the basic descriptive statistics of the debt ratio are shown before and after the headquarters changed. The obtained mean values higher than 1 in Table 1 and Table 3 are affected by the negative reported values of equity in the provided financial statements.

Due to the high variability of the debt ratios, the arithmetic average has low reporting ability, so we focus on median values in the evaluation with respect to the diameter. The median value of the debt ratios has increased for $7.8 \%$, from the 0.77 to 0.83 . To verify a statistically significant difference, the nonparametric Wilcoxon signed rank test was used. (Table 2).

Although the test results confirm statistically significant difference in the value of the debt ratio of firms before and after the relocation of the registered office ( $p$-value $=0.00$ ), the share of the companies that increased the indicator after the relocation of the registered office is $56 \%$, which does not sufficiently imply that the debt ratios are rising after the relocation of the registered office. For this reason, the given indicator from the point of view of the jurisdiction category was analysed, where it was verified whether the use of debt as a profit transfer technique is typical for a particular jurisdiction category. Table 3 captures changes in median values for the investigated marker. The most significant increase in the value of the indicator is in mid-shore jurisdictions (an increase of 20\%) and the least significant difference is in the onshore jurisdictions' category (2\%).

The Wilcoxon signed ranks test results are shown in Table 4. The statistically significant difference was shown only for mid-shore categories (for offshore categories only at the significance level of 0.1 ). When there is a focus on the share of companies that have grown in individual jurisdictions, the onshore category has grown to $51 \%$, to $60 \%$ in midshore and $64 \%$ in offshore.

The results achieved correspond to our expectations mainly in the mid-shore category. Cyprus and Malta are used by Slovak companies mainly because of relatively flexible options in the field of tax optimization (e.g. participation exemption, advanced tax rulings, patent box, signed double tax treaties with some offshore jurisdictions, shareholders entitled to a tax refund of 6/7ths or access to the EU Directives). If the offshore property is used on a first-line ownership basis (generally regardless of jurisdiction), the creation of this international corporate structure primarily seeks to achieve the benefit of the actual owner's anonymity. If the offshore company is the first owner of the property, the use of profit transfer methods and techniques is significantly limited as the Slovak Republic does not have a 35\% withholding tax. At the same time, the ownership link with jurisdictions from the midshore and offshore category brings a significantly worse image than the onshore category. 
Table 1. Descriptive statistics of debt ratio

\begin{tabular}{|l|c|c|}
\hline \multicolumn{1}{|c|}{ Statistics } & BEFORE & AFTER \\
\hline N Valid & 989 & 989 \\
Missing & 0 & 0 \\
\hline Mean & 1.0508 & 1.1234 \\
\hline Median & 0.7710 & 0.8315 \\
\hline Std. Deviation & 1.8435 & 1.7396 \\
\hline
\end{tabular}

Table 2. Wilcoxon signed ranks test (debt ratio)

\begin{tabular}{|c|l|c|c|c|}
\hline & \multicolumn{1}{|c|}{ Ranks } & N & Mean Rank & Sum of Ranks \\
\hline \multirow{4}{*}{$\begin{array}{c}\text { AFTER } \\
\text { less } \\
\text { BEFORE }\end{array}$} & Negative Ranks & $431^{\mathrm{a}}$ & 484.76 & 208933.0 \\
\cline { 2 - 5 } & Positive Ranks & $558^{\mathrm{b}}$ & 502.91 & 280622.0 \\
\hline & Ties & $0^{\mathrm{c}}$ & & \\
\hline & Total & 989 & & \\
\hline \multirow{5}{*}{} & Test Statistics & & & \\
\cline { 2 - 5 } & Z & $-3.989^{\mathrm{d}}$ & & \\
\hline & Asymp.Sig (2-tailed) & 0.000 & & \\
\hline
\end{tabular}

Note: ${ }^{\mathrm{a}}$ AFTER < BEFORE, ${ }^{\mathrm{b}}$ AFTER $>$ BEFORE, ${ }^{\mathrm{c}}$ AFTER $=$ BEFORE, ${ }^{\mathrm{d}}$ based on negative ranks.

Table 3. Descriptive statistics of the debt ratio according to jurisdiction

\begin{tabular}{|c|c|c|c|}
\hline Jurisdiction & Statistics & BEFORE & AFTER \\
\hline \multirow{4}{*}{ ONSHORE } & $\begin{array}{ll}\text { N Valid } \\
\\
\text { Missing }\end{array}$ & $\begin{array}{c}460 \\
0\end{array}$ & $\begin{array}{c}460 \\
0\end{array}$ \\
\hline & Mean & 1.1376 & 1.1124 \\
\hline & Median & 0.7865 & 0.8028 \\
\hline & Std. Deviation & 1.7326 & 1.7737 \\
\hline \multirow{4}{*}{ MIDSHORE } & $\begin{array}{ll}\text { N Valid } \\
\\
\text { Missing }\end{array}$ & $\begin{array}{c}417 \\
0\end{array}$ & $\begin{array}{c}417 \\
0\end{array}$ \\
\hline & Mean & 0.9639 & 1.1586 \\
\hline & Median & 0.7357 & 0.8849 \\
\hline & Std. Deviation & 1.8622 & 1.7618 \\
\hline \multirow{4}{*}{ OFFSHORE } & $\begin{array}{l}\text { N Valid } \\
\text { Missing }\end{array}$ & $\begin{array}{c}112 \\
0\end{array}$ & $\begin{array}{c}112 \\
0\end{array}$ \\
\hline & Mean & 1.0181 & 1.0371 \\
\hline & Median & 0.8463 & 0.8843 \\
\hline & Std. Deviation & 2.1865 & 1.5103 \\
\hline
\end{tabular}


Table 4. Wilcoxon signed ranks test according to jurisdiction (debt ratio)

\begin{tabular}{|c|c|c|c|c|c|}
\hline Jurisdiction & & Ranks & $\mathrm{N}$ & Mean Rank & Sum of Ranks \\
\hline \multirow{12}{*}{$\begin{array}{c}\text { AFTER } \\
\text { less } \\
\text { BEFORE }\end{array}$} & \multirow{4}{*}{ ONSHORE } & Negative Ranks & $225^{\mathrm{a}}$ & 22.14 & 51331.0 \\
\hline & & Positive Ranks & $235^{\mathrm{b}}$ & 23.76 & 54699.0 \\
\hline & & Ties & $0^{c}$ & & \\
\hline & & Total & 460 & & \\
\hline & \multirow{4}{*}{ MIDSHORE } & Negative Ranks & $166^{\mathrm{a}}$ & 197.89 & 32850.0 \\
\hline & & Positive Ranks & $251^{\mathrm{b}}$ & 216.35 & 54303.0 \\
\hline & & Ties & $0^{c}$ & & \\
\hline & & Total & 417 & & \\
\hline & \multirow{4}{*}{ OFFSHORE } & Negative Ranks & $40^{\mathrm{a}}$ & 62.85 & 2514.0 \\
\hline & & Positive Ranks & $72^{\mathrm{b}}$ & 52.97 & 3814.0 \\
\hline & & Ties & $0^{c}$ & & \\
\hline & & Total & 112 & & \\
\hline & & Test Statistics & & & \\
\hline & \multirow{2}{*}{ ONSHORE } & $\mathrm{Z}$ & $-0.590^{\mathrm{d}}$ & & \\
\hline & & Asymp. Sig. (2-tailed) & 0.555 & & \\
\hline & \multirow{2}{*}{ MIDSHORE } & Z & $-4.356^{\mathrm{d}}$ & & \\
\hline & & Asymp. Sig. (2-tailed) & 0.000 & & \\
\hline & \multirow{2}{*}{ OFFSHORE } & Z & $-1.887^{\mathrm{d}}$ & & \\
\hline & & Asymp. Sig. (2-tailed) & 0.059 & & \\
\hline
\end{tabular}

Note: ${ }^{\text {a }}$ AFTER < BEFORE, ${ }^{\mathrm{b}}$ AFTER $>$ BEFORE, ${ }^{\mathrm{c}}$ AFTER $=$ BEFORE, ${ }^{\mathrm{d}}$ based on negative ranks.

Our analysis only deals with the first level of ownership structure, and in practice, most international corporate structures are set on two levels at a minimum, i.e., mid-shore company is then further owned, for example, by offshore company (tax benefits and anonymity of the ultimate beneficial owner combined). For data analysis only at the first level, it is really difficult to evaluate individual transactions in detail, but we can identify the use of individual techniques, respectively to identify trends in the behavior of Slovak companies.

Furthermore, the same analysis was preformed between Slovak firms with links to lower tax jurisdictions and between those with no ownership links to lower tax jurisdictions. The database covering the year 2015 was used and also data covering 173,121 Slovak companies based in Slovakia and 2,204 with links and tax havens. In the analysis, work was based on a randomly generated $2 \%$ of the non-tax group companies and compared the value of the pointer in both groups rather than using the entire dataset of companies without links to tax havens. If companies use debt as a channel to transfer taxable income to a tax haven, the value of the debt ratios in firms with tax havens should show a higher value compared to companies with no links to lower tax jurisdictions. The values of the descriptive ratios of the debt ratio for both groups of enterprises are shown in Table 5. The median value of the given ratio is 1.2 times higher for companies with links to tax havens than for companies without them. 
Table 5. Descriptive statistics of debt ratio

\begin{tabular}{|l|c|c|}
\hline \multicolumn{1}{|c|}{ Statistics } & Without links & With links \\
\hline $\begin{array}{l}\text { N Valid } \\
\text { Missing }\end{array}$ & 3324 & 2407 \\
& 0 & 0 \\
\hline Mean & 0.8455 & 0.9392 \\
\hline Median & 0.6514 & 0.7868 \\
\hline Std. Deviation & 1.0632 & 1.1490 \\
\hline
\end{tabular}

Table 6. Mann Whitney test (debt ratio)

\begin{tabular}{|l|l|c|c|c|}
\hline \multicolumn{1}{|c|}{ Ranks } & N & Mean Rank & Sum of Ranks \\
\hline \multirow{4}{*}{$\begin{array}{c}\text { DEBT } \\
\text { per } \\
\text { ASSETS }\end{array}$} & Without links & 3324 & 2751.4 & 9145709.5 \\
\hline & With links & 2407 & 3024.2 & 7279336.5 \\
\hline & Total & 5731 & & \\
\hline \multirow{5}{*yyyy}{} & Test Statistics & & & \\
\cline { 2 - 5 } & Mann-Whitney U & 3619559.5 & & \\
\cline { 2 - 5 } & Wilcoxon W & 9145709.5 & & \\
\cline { 2 - 5 } & Z & -6.161 & & \\
\cline { 2 - 5 } & Asymp.Sig (2-tailed) & 0.000 & & \\
\hline
\end{tabular}

A statistically significant difference was also confirmed by the nonparametric Mann Whitney test ( $\mathrm{p}$-value $=0$ ). A lower mean rank for a group of businesses without links to tax ranges in Table 6 confirms our assumption that firms with ownership links to tax havens have higher ratios of debt ratios. Based on the results obtained, it is therefore possible to confirm the existence of debt utilization as a tax optimization technique, respectively using debt as well as a profit-shifting channel.

As already mentioned in the previous section, the use of debt is closely linked to the possibility of deducting interest expenses. Except the debt financing, most of the creditors have several legal possibilities to control the company. Previous research (Ištok \& Kanderová, 2019) was aimed at changing the reported interest expenses per assets before and after the relocation of the registered office of the Slovak company to the tax haven, and also the comparison of the reported indicator among Slovak companies with and with no ownership links to tax havens. Given that the possibility of deduction of interest expenses is a subset of debt use in international tax planning, we consider as necessary to mention our previous empirical results in this area to complete the investigated area of debt. First empirical evidence is that the Slovak companies after the change of the registered office reported the increase of the investigated indicator by $75 \%$. The difference was shown also to be statistically significant only for companies in the mid-shore jurisdiction (at the significant level of 0.01). Furthermore, the statistical difference was recorded only for the NACE sector of wholesale, retail and repair of motor vehicles (530\% increase of median value after the change of the registered office). Second empirical evidence is that the Slovak companies located in tax havens 
reported for the year 2015 the median value of the investigated indicator (interest expenses per assets) $41 \%$ higher than companies with no ownership links to tax havens (statistically significant difference).

\subsection{Debt per sales analysis}

In the next part of the analysis, the focus is on the analysis of the debt per sales indicator. From a file of 1,257 companies, companies that showed zero or negative revenue were excluded and also those where the indicator appeared to be outlier. The resulting set contained 617 companies with debt ratios for the sales ratio before and after the headquarters had moved. The Wilcoxon signed ranks test did not show a statistically significant difference in the value of the indicator before and after the change of residence ( $\mathrm{p}$-value $=0.808$ ). In $52 \%$ of companies, the indicator went down after the change of the registered office.

As with the debt ratios, there were relatively small observations compared to the total number of Slovak firms that had links to lower tax jurisdictions. This is mainly due to two reasons. The first reason - the main reason is that Slovak companies were obliged to record financial statements only as of 2014, some companies do not fulfil this obligation to this day. A similar problem is noted not only in the Slovak republic but also in the Czech Republic in some sectors. In the past, in the academic sphere, data sources for tax analyses have been addressed, especially when estimating the marginal tax rate, where if the balance sheet generate boisterous measures of taxable income, then the tax return data would seem to represent a considerable improvement. For example, Graham and Mills (2008) used confidential tax return data and found that the simulated tax rates using book estimates of taxable income appear superior to those based on taxable income reported on the U.S. tax return. One of their explanations is that for multinational firms, consolidated financial accounting reports give a better view of worldwide tax status relative to U.S. tax return data that excluded the income of foreign subsidiaries (Hanlon \& Heitzman, 2010). The second reason is that more than $30 \%$ of Slovak companies with ownership links with tax havens have this link since their formation, so we do not have the data available before the transfer of the registered office.

Specifically, the indicator for each category of jurisdiction was analysed separately. Table 7 shows the changes of descriptive characteristics for the investigated indicator. In all jurisdictions, the value of the median indicator has increased. The highest increase was in the offshore jurisdictions' category by $140 \%, 25 \%$ in the mid-shore category, and the smallest increase was recorded in onshore categories (9\%).

Table 8 shows the results of the Wilcoxon signed ranks test, from which it is possible to quantify the share of enterprises when the indicator has risen. In the onshore and mid-shore categories, more than $50 \%$ of companies experienced a decline in the indicator. In offshore categories, the record shows $67 \%$ of companies with an increase in the indicator. A statistically significant difference is only for offshore categories, when the indicator has increased after the location moved. Taking into consideration only the category of the offshore jurisdictions (the set contains 73 companies), the increase in the indicator was mainly due to:

- the current increase in both sales and liabilities (41\% of companies), of which commitments increased faster (multiplied) than sales, resulting in an increase in the indicator of $61 \%$ of enterprises; 
Table 7. Descriptive statistics of the debt per sales according to jurisdiction

\begin{tabular}{|c|l|c|c|}
\hline Jurisdiction & \multicolumn{1}{|c|}{ Statistics } & BEFORE & AFTER \\
\hline \multirow{5}{*}{ ONSHORE } & N Valid & 329 & 329 \\
& Missing & 0 & 0 \\
\cline { 2 - 4 } & Mean & 2.8871 & 3.3874 \\
\cline { 2 - 4 } & Median & 0.4539 & 0.4967 \\
\cline { 2 - 4 } & Std. Deviation & 5.9135 & 9.7112 \\
\hline \multirow{5}{*}{ MIDSHORE } & N Valid & 215 & 215 \\
& Missing & 0 & 0 \\
\cline { 2 - 4 } & Mean & 2.2411 & 2.1524 \\
\cline { 2 - 4 } & Median & 0.5095 & 0.6415 \\
\cline { 2 - 4 } & Std. Deviation & 4.4244 & 3.7501 \\
\hline \multirow{5}{*}{ OFFSHORE } & N Valid & 73 & 73 \\
& Missing & 0 & 0 \\
\cline { 2 - 4 } & Mean & 2.2848 & 2.9008 \\
\cline { 2 - 4 } & Median & 0.3030 & 0.7272 \\
\cline { 2 - 4 } & Std. Deviation & 4.9251 & 4.6010 \\
\hline
\end{tabular}

Table 8. Wilcoxon signed ranks test according to jurisdiction (debt per sales)

\begin{tabular}{|c|c|c|c|c|c|}
\hline Jurisdiction & & Ranks & $\mathrm{N}$ & Mean Rank & Sum of Ranks \\
\hline \multirow{12}{*}{$\begin{array}{c}\text { AFTER } \\
\text { less } \\
\text { BEFORE }\end{array}$} & \multirow{4}{*}{ ONSHORE } & Negative Ranks & $188^{\mathrm{a}}$ & 162.09 & 30473.0 \\
\hline & & Positive Ranks & $141^{\mathrm{b}}$ & 168.88 & 23812.0 \\
\hline & & Ties & $0^{c}$ & & \\
\hline & & Total & 329 & & \\
\hline & \multirow{4}{*}{ MIDSHORE } & Negative Ranks & $109^{\mathrm{a}}$ & 107.48 & 32850.0 \\
\hline & & Positive Ranks & $106^{\mathrm{b}}$ & 216.35 & 54303.0 \\
\hline & & Ties & $0^{c}$ & & \\
\hline & & Total & 417 & & \\
\hline & \multirow{4}{*}{ OFFSHORE } & Negative Ranks & $40^{\mathrm{a}}$ & 62.85 & 2514.0 \\
\hline & & Positive Ranks & $72^{\mathrm{b}}$ & 52.97 & 3814.0 \\
\hline & & Ties & $0^{c}$ & & \\
\hline & & Total & 112 & & \\
\hline & & Test Statistics & & & \\
\hline & \multirow{2}{*}{ ONSHORE } & $\mathrm{Z}$ & $-0.590^{\mathrm{d}}$ & & \\
\hline & & Asymp. Sig. (2-tailed) & 0.555 & & \\
\hline & \multirow{2}{*}{ MIDSHORE } & $\mathrm{Z}$ & $-4.356^{\mathrm{d}}$ & & \\
\hline & & Asymp. Sig. (2-tailed) & 0.000 & & \\
\hline & \multirow{2}{*}{ OFFSHORE } & $\mathrm{Z}$ & $-1.887^{\mathrm{d}}$ & & \\
\hline & & Asymp. Sig. (2-tailed) & 0.059 & & \\
\hline
\end{tabular}

Note: ${ }^{\text {a }}$ AFTER < BEFORE, ${ }^{\mathrm{b}}$ AFTER $>$ BEFORE, ${ }^{\mathrm{c}}$ AFTER = BEFORE, ${ }^{\mathrm{d}}$ based on negative ranks. 
- the current decline in revenues and liabilities (26\% of enterprises), of which commitments declined more slowly (less) sales, resulting in an increase in the indicator of $58 \%$ of enterprises;

- an increase in commitments and a decrease in revenues, leading to a $26 \%$ increase in the indicator;

- decrease in liabilities and increase in sales (7\%), which caused a drop in the indicator.

Based on the obtained results, it can be interpreted that the offshore category is predominantly for companies that have already reached a certain level of revenue compared to the onshore or mid-shore category, where the sales of the headquarters have seen an increase (companies have probably assumed that future growth will occur within mid-shore categories or will no longer be significant in offshore categories).

The Enterprise Database for 2015 was also used, data was available for 142,219 companies based in the Slovak Republic and 1,459 companies with links to lower tax jurisdictions.

In the analysis, the entire business dataset of firms without ownership links to lower tax havens jurisdictions was not used. The value of the pointer in both categories was compared within a randomly generated $2 \%$ of non-tax-related companies (2,895 observations). Descriptive characteristics are given in Table 9 and Mann Whitney test results in Table 10.

When assessing debt as a technique of transferring taxable profit to the tax haven, two indicators were used - debt per assets and debt per sales were used. In evaluating these indicators, two approaches were applied. Firstly, the change of indicator was analysed for those companies that moved their seat to the tax haven. Selected indicators were evaluated based on comparison of median values before and after relocation, by testing a statistically

Table 9. Descriptive statistics of debt per sales

\begin{tabular}{|l|c|c|}
\hline \multicolumn{1}{|c|}{ Statistics } & Without links & With links \\
\hline N Valid & 2895 & 1459 \\
Missing & 0 & 0 \\
\hline Mean & 0.9068 & 1.6301 \\
\hline Median & 0.3646 & 0.4580 \\
\hline Std. Deviation & 1.4795 & 2.3146 \\
\hline
\end{tabular}

Table 10. Mann Whitney test (debt per sales)

\begin{tabular}{|l|l|c|c|c|}
\hline & \multicolumn{1}{|c|}{ Ranks } & N & Mean Rank & Sum of Ranks \\
\hline \multirow{4}{*}{$\begin{array}{c}\text { DEBT } \\
\text { per } \\
\text { SALES }\end{array}$} & Without links & 2895 & 2067.56 & 5985580.5 \\
\cline { 2 - 5 } & With links & 1459 & 2395.65 & 3495254.5 \\
\cline { 2 - 5 } & Total & 4354 & & \\
\hline \multirow{5}{*}{} & Test Statistics & & & \\
\cline { 2 - 5 } & Mann-Whitney U & 1793620.5 & & \\
\cline { 2 - 5 } & Wilcoxon W & 5985580.5 & & \\
\cline { 2 - 5 } & Z & -8.129 & & \\
\cline { 2 - 5 } & Asymp.Sig (2-tailed) & 0.000 & & \\
\hline
\end{tabular}


significant difference in the value of a given indicator before and after the transfer of the registered office, as well as by quantifying the share of enterprises in which the indicator has been rising. Regardless of the type of jurisdiction, a more pronounced change in the median value was the debt per sales (increase of 22.6\%) compared to the debt per assets (increase of $7.8 \%)$. On the other hand, the statistically significant difference was only demonstrated for the debt per assets indicator.

For the next step, the focus was on the use of debt financial instruments as a profit shift channel whether it is related to the jurisdiction category. The results of the analysis show that in the case of onshore jurisdiction this channel is not a commonly used technique. In the case of the jurisdictions on both sides, there was minimal change in their median value, there was also no statistically significant difference, and the proportion of companies with a debt increase per assets was $51 \%$ and even less than $50 \%$ of the debt on sales. More significant evidence of an increase in median value and share of a company with an increase in measured indicators following a change of registered office have been shown in mid-shore and offshore jurisdictions. The analysis was supplemented by a different view when we compared the selected indicators to a group of businesses with linkage to tax havens and without linkage to tax havens. For both indicators, a statistically significant difference in their values with higher value in affiliated companies was confirmed.

\section{Conclusions}

The results of our research confirm that Slovak companies linked to tax havens have higher debt ratios than their counterparts. The median value of leverage increased by $7.8 \%$ after the relocation of the registered office of Slovak companies. During the period under review, the corporate income tax rate $(19 \%, 23 \%, 22 \%)$ often changed in the Slovak Republic. If we only get an increase from $19 \%$ to $23 \%$, this represents a $21 \%$ increase in the corporate income tax rate. Our results confirm that using debt by companies in Slovakia represent a significant channel of profit-shifting. These conclusions are comparable to those of Desai et al. (2004). If we consider the outcomes of Martinez and Ramalho's research (2014), where debt per assets is the key indicator to measure tax aggression, then we can state that Slovak companies are more tax aggressive in using the debt channel as a technique for profit shifting (the Thin-capitalization rules were introduced in the Slovak Republic as of 2015). In view of the growth of the corporate income tax rate over the period under review, our results are consistent with Graham (1996), so high-tax firms use more debt than firms with low-tax rates. Although several variables affect the use of debt, the results of our analysis imply a tendency for Slovak companies to use this technique (debt technique) as a channel for the transfer of profit. This tendency is more pronounced in midshore and offshore jurisdictions. The median debt ratio is higher for taxpayers with ownership to tax havens than for companies without links to tax havens. In the field of this technique (debt), it would be interesting in Slovak conditions to also monitor the correlation between tax avoidance and corporate debt maturity similar to Kubick and Lockhart (2017) respectively. To look in more detail on selected jurisdictions without categorization, such as Janský and Kokeš (2015). The overall importance of debt as a profit-shifting technique will be evaluated only after analysing other 
channels of profit-shifting with regard to the setting of the Slovak tax system (e.g. already mentioned thin-capitalization rules or other unilateral provisions).

From a macroeconomic point of view (essentially microeconomic) in Slovak conditions, it will be important to monitor, the introduction of thin-capitalization rules that affect dividend and financing decisions and whether they can partly explain why corporations receive both debt and equity (and their relationship). The methodology of this research can be conceived similarly to Maßbaum and Sureth-Sloane (2009), i.e. the Belgian, German and Italian rules as examples. Threats and obstacles to future research in Slovak conditions are mainly brought about by a frequent change in tax legislation (except for frequent changes in corporate income tax rates, further changes in dividend taxation, changes in research and development incentives, and many others). Strategic management generally holds that for a company to survive and to be successful in a particular sector, it must reconcile the aggressiveness of its behaviour with the frequency of changes in the external environment. The Slovak Income Tax Act is characterized by frequent changes in the monitored period (2005-2015), which has been revised more than 50 times. While our current research has consistently confirmed the use of individual methods and techniques for the transfer of taxable income (in this case debt), in further research, it is necessary to focus on compiling empirical evidence that Slovak firms with ownership links to tax havens suffer lower tax liability than those without (and derived also a lower effective tax rate of corporate income tax). If the use of tax evasion techniques has been verified, logically, a lower tax burden, or reported lower paid taxes, should also be confirmed. The statistically significant difference in the ratio of debt per sales before and after linking to the tax havens has not been demonstrated despite the $22.6 \%$ increase in the median value. Statistical significance has only been demonstrated in offshore jurisdictions. In this category, the increase in the debt per sales indicator was mainly due to a slower increase in sales compared to the increase in liabilities. Observed was a faster decline in sales compared to a decline in liabilities. In the future, not only debt but also non-debt tax channels of profit shifting should be considered in the field of research, as the offshore jurisdiction over the first level of ownership is used primarily to cover the anonymity of the ultimate beneficial owner.

From the point of view of tax optimization, it was assumed that our analysis also confirmed that the midshore category is mainly used for tax optimization. It is clear, therefore, that Slovak companies, whose primary objective is tax optimization (of course, in addition to the anonymity of the actual owner at the next ownership level) and expecting an increase in revenues, are most likely to choose midshore jurisdictions.

\section{Funding}

This work was supported by the Vedecká grantová agentúra Ministerstva školstva, vedy, výskumu a športu Slovenskej republiky Slovenskej akadémie vied under Grant [1/0767/18].

\section{Disclosure statement}

The authors declare that they do not have any competing financial, professional, or personal interests from other parties. 


\section{References}

Auerbach, A., Devereux, M. P., Keen, M., \& Vella, J. (2017). International tax planning under the destination-based cash flow. National Tax Journal, 70(4), 783-802. https://doi.org/10.17310/ntj.2017.4.04

Bisnode. (2018). Daňové raje prišli o desiatky slovenských firiem. Retrieved from https://www.bisnode. sk/o-bisnode/o-nas/novinky/danove-raje-prisli-o-desiatky-slovenskych-fririem

Blouin, J., Core, J. E., \& Guay, W. (2010). Have the tax benefits of debt been overestimated? Journal of Financial Economics, 98(2), 195-213. https://doi.org/10.1016/j.jineco.2010.04.005

Chen, S., Chen, X., Chen, Q., \& Shevlin, T. (2007). Are family firms more tax aggressive than non- family firms? Journal of Financial Economics, 95(1), 41-61. https://doi.org/10.1016/j.jfineco.2009.02.003

Chen, S., Huang, Y., Li, N., \& Shevlin, T. (2019). How does quazi-indexer ownership affect corporate tax planning. Journal of Accounting and Economics, 67(2-3), 278-296. https://doi.org/10.1016/j.jacceco.2018.01.001

Clemente-Almendros, J. A., \& Sogorb-Mira, F. (2018). Costs of debt, tax benefits and a new measure of non-debt tax shields: examining debt conservatism in Spanish listed firms. Revista de Contabilidad, 21(2), 162-175. https://doi.org/10.1016/j.rcsar.2018.05.001

Desai, M. A., Foley, C. F., \& Hines, J. R. (2004). A Multinational Perspective on Capital Structure Choice and Internal Capital markets. The Journal of Finance, 59(6), 2451-2487. https://doi.org/10.1111/j.1540-6261.2004.00706.x

Graham, J. R. (1996). Debt and the marginal tax rate. Journal of Financial Economics, 41(1), 41-73. https://doi.org/10.1016/0304-405X(95)00857-B

Graham, J. R., \& Tucker, A. L. (2006). Tax shelters and corporate debt policy. Journal of Financial Economics, 81(3), 563-594 https://doi.org/10.1016/j.jfineco.2005.09.002

Graham, J. R., \& Mills, L. F. (2008). Using tax return data to simulate corporate marginal tax rates. Journal of Accounting and Economics, 46(2-3), 366-288. https://doi.org/10.1016/j.jacceco.2007.10.001

Hanlon, M., \& Heitzman, S. (2010). A review of tax research. Journal of Accounting and Economics, 50(2-3), 127-178. https://doi.org/10.1016/j.jacceco.2010.09.002

Isin, A. A. (2018). Tax avoidance and cost of debt: The case for loan-specific risk mitigation and public debt financing. Journal of Corporate Finance, 49, 344-378. https://doi.org/10.1016/j.jcorpfin.2018.01.003

Ištok, M., \& Kanderová, M. (2019). Interest expenses as a technique of profit shifting used by Slovak companies. In Inetrnationa Scientific Conference Hradec Economic Days 2019, Part I. Hradec Králové, Czech Republic, 9(1), 292-304.

Janský, P., \& Kokeš, O. (2015). Corporate tax base erosion and profit-shifting out of the Czech Republic. Post-Communist Economies, 27(4), 537-546. https://doi.org/10.1080/14631377.2015.1084733

Janský, P., \& Kokeš, O. (2016). Profit-shifting from Czech multinational companies to European tax havens. Applied Economics Letters, 23(16), 1-19. https://doi.org/10.1080/13504851.2015.1137543

Johannesen, N. (2014). Tax avoidance with cross-border hybrid instruments. Journal of Public Economics, 112, 40-52. https://doi.org/10.1016/j.jpubeco.2014.01.011

Krejčí, P. (2016). Vlastnické struktury a Compliance. In Odborní konference Mezinárodní struktury Adaptace na aktuální legislativní zmèny. 26 April 2016, Akonttust company. Prague.

Kubick, T. R., \& Lockhart, G. B. (2017). Corporate tax aggressiveness and the maturity structure of debt. Advances in Accounting, 36, 50-57. https://doi.org/10.1016/j.adiac.2016.10.001

Lee, Z., Deng, S., Lin, B., \& Yang, J. G. S. (2010). Decision model and analysis for investment interest expense deduction and allocation. European Journal of Operational Research, 200(1), 268-280. https://doi.org/10.1016/j.ejor.2008.12.012 
Lin, S., Tong, N., \& Tucker, A. L. (2014). Corporate tax aggression and debt. Journal of Banking Finance, 40, 227-241. https://doi.org/10.1016/j.jbankfin.2013.11.035

Maßbaum, A., \& Sureth, C. (2009). Thin capitalization rules and entrepreneurial capital structure decisions. BuR Business Research Journal, 2(2), 147-169. https://doi.org/10.1007/BF03342708

Martinez, A. L., \& Ramalho, G. C. (2014). Family firms and Tax aggressiveness in Brazil. International Business Research, 7(3), 129-136. https://doi.org/10.5539/ibr.v7n3p129

Miniaci, R., Parisi, M. L., \& Panteghini, P. M. (2014). Debt Shifting in Europe. International Tax and Public Finance, 21(3), 397-435. https://doi.org/10.1007/s10797-012-9266-4

Moravec, L., \& Kukalová, G. (2014). Investments allocation tax factors in pre-crisis time. In European Financial Systems 2014. Proceedings of the 11th International Scientific Conference (pp. 396-402). Masaryk University, Brno.

Moravec, L., Rohan, J., \& Hinke, J. (2019). Estimation of international tax planning impact on corporate tax gap in the Czech Republic. E\&M Ekonomie a Management, 22(1), 157-170. https://doi.org/10.15240/tul/001/2019-1-011

Overesch, M., \& Wamser, G. (2014). Bilateral internal debt financing and tax planning of multinational firms. Review of Quantitative Finance and Accounting, 42(2), 191-209. https://doi.org/10.1007/s11156-012-0339-3

Reuter, P. (2012). Draining development? Controlling flows of illicit funds from developing countries. World Bank License: CC BZ 3.0 IGO. Retrieved from https://openknowledge.worldbank.org/handle/10986/2242. https://doi.org/10.1596/978-0-8213-8869-3

Riedel, N. (2018). Quantifying international tax avoidance: A review of academic literature. Review of Economics, 69(2), 169-182. https://doi.org/10.1515/roe-2018-0004

Rohan, J., \& Moravec, L. (2017). Tax information exchange influence on Czech based companies' behaviour in relation to tax havens. Acta Universitatis Agriculturae et Silviculturae Mendelianae Brunensis, 65(2), 721-726. https://doi.org/10.11118/actaun201765020721

Scholes, M. S., Wolfson, M. A., Erickson, M. M., Maydew, E. L., \& Shevlin, T. J. (2009). Taxes and business strategy: A planning approach. (4th $\mathrm{ed}$.). New Jersey: Pearson Prentice-Hall.

Valencia, M. (2013). Storm survivors. The Economist. Retrieved from https://www.economist.com/ special-report/2013/02/16/storm-survivors 